\title{
Zeszyty PRASOZNAWGZE
}

Kraków 2020, t. 63, nr 1 (241), s. 115-132

DOI: 10.4467/22996362PZ.20.008.11516

www.ejournals.eu/Zeszyty-Prasoznawcze/

\section{NARRACJA JAKO NARZĘDZIE ROSYJSKIEJ PROPAGANDY. REWOLUCJA „ŻÓŁTYCH KAMIZELEK” W RELACJACH SIECIOWYCH ROSYJSKICH MEDIÓW PROPAGANDOWYCH}

\author{
Grażyna Piechota \\ orcid.org/0000-0002-0662-5074 \\ Wydział Zarządzania i Komunikacji Społecznej \\ Krakowska Akademia im. Andrzeja Frycza Modrzewskiego
}

\begin{abstract}
Media Narrative as a Russian Propaganda Tool. The "Yellow Vests" Revolution in France as Presented in Network Reports of Russian Propaganda Media
\end{abstract}

The article concerns the propagandist influence of the media narratives created during political protests. The results of research carried out during the "Yellow Vests" revolution in France, present the activity of Russian propaganda media. The quantitative analysis confirmed the hypothesis that the propaganda narrative does not have to involve creating fake news and trolling, or disinformation activities that are usually the domain of interference of the Russian Federation in the information security of third countries. Instead, effectively implemented propaganda can take the form of an intensive coverage of events that builds a narrative fostering the fulfillment of propaganda goals. The article shows the important role of social media used as a channel of "telling" stories about political protests, to strengthen the phenomenon of cyberpolarisation. Creating the network enclaves of deliberation effectively sustains interest in the protest, increasing the range of information about it and activating antagonisms between social groups.

Keywords: "Yellow Vests", political protests, France, Russian propaganda media, social media

\section{Wstęp}

Opowiadana historia (storytelling) staje się istotnym elementem oddziaływania na duże grupy społeczne ulegające umiejętnie prowadzonej manipulacji emocjami i nastrojami społecznymi. Maciej Bachryj-Krzywaźnia uważa, że opowiadanie historii opartej na komunikowaniu idei staje się skutecznym sposobem zarządzania 
wyobraźnią odbiorcy. Autor dowodzi, że narracyjność stanowi „uniwersalną formę ludzkiego doświadczenia i rozumienia rzeczywistości" (Bachryj-Krzywaźnia 2019, s. 195) Wynika to ze struktury poznawczej porządkującej bodźce poznawcze w formę opowieści, która za pomocą uporządkowanych i chronologicznych całości tworzy strukturę perswazyjnej historii przekazywanej w sposób fabularyzowany. $\mathrm{W}$ przypadku skutecznego storytellingu za istotne należy uznać

[...] umocowanie komunikatu w jakiejś bardziej uniwersalnej historii, ukazanie jej na kanwie toposu stanowiącego ważną składową świadomości zbiorowej. Stąd pojawiają się odwołania do archetypów i mitów jako wzorców fabularnych przydatnych w konstruowaniu opowieści, czy też próby zredukowania wielości narracji do kilku uniwersalnych kulturowo typów (Bachryj-Krzywaźnia 2019, s. 197).

Jacek Wasilewski i Tomasz Olczyk, koncentrując się na zdolnościach poznawczych, piszą:

Możliwości umysłu w zakresie przetwarzania informacji są ograniczone ilością posiadanych zasobów mentalnych (tego, co mogę pojąć) oraz procedurami ich dystrybucji (do czego mogę to dopasować i co wtedy stracę/zyskam). [...] Zrozumienie narracji wymaga więc dopasowania fragmentu do całości układanki, czyli reprezentacji wiedzy o świecie. [...] Narracje polityczne powalają nawigować nam po świecie społecznym i pomijać to, co wydaje się nie pasować do schematu (Wasilewski, Olczyk 2017, s. 45).

Podobnie uważa Kinga Stopczyńska, podkreślając wymóg atrakcyjności opowieści w oczach odbiorców (Stopczyńska 2016, s. 318). Opowieść stanowi podstawowy sposób przekazania otoczeniu własnej perspektywy i przedstawienia wyznawanych wartości. Umożliwia tym samym oddanie złożonych emocji, które torują drogę idei wpływającej na postawy osób i grup, do których przekaz jest adresowany. Treści rozwijające opowiadaną historię angażują jej odbiorców, którzy utożsamiają się $\mathrm{z}$ bohaterami akcji albo podzielają emocje towarzyszące działaniom podejmowanym przez bohaterów.

W niniejszym artykule narracja została zdefiniowana utylitarnie. Uznano ją za opowiadanie historii identyfikowanej ideologicznie i potraktowano jako zjawisko, którego celem jest zarządzanie świadomością zbiorową poprzez odwołanie do podzielanych wartości oraz stereotypów kulturowych. Rosyjskie oddziaływanie propagandowe na protesty polityczne rozgrywające się we Francji ma charakter ukierunkowanego i zintensyfikowanego relacjonowania wydarzeń. Nicholas Vinocur z Politico wskazał, że w nowych mediach wzrasta rola rosyjskiej propagandy, oddziałującej na przebieg wydarzeń podczas rewolucji „żółtych kamizelek”. Vinocur zwraca uwagę na to, że fałszywe lub wprowadzające w błąd informacje wpłynęły na wzmocnienie ruchu „żółtych kamizelek”. Jednocześnie zaznacza, że informacje nieprawdziwe lub wprowadzające w błąd tworzone były w celu ich rozprzestrzeniania sieciowego głównie przez rodzimych, francuskich twórców 
(Politico 2019). Materiały pochodzące z RT $\mathrm{RT}^{\mathbf{1}}$ były raczej obiektywne, a ich celem było wzmacnianie protestów i rozwijanie wokół nich ruchu sieciowego. Adam Lelonek uważa, że ważnym elementem rosyjskich działań jest „instalowanie narracji”, której celem jest osiągnięcie wysokiego stanu polaryzacji społecznej i wywołanie chaosu informacyjnego. W tym stanie ułatwione jest bowiem prowadzenie innych działań o charakterze politycznym (Polskie Radio 24 2019). Procesowi kreacji spolaryzowanych grup (group polarization) sprzyja dyskurs, który powoduje, że jednostki radykalizują swoje poglądy względem tych, jakimi kierowali się początkowo, co w dalszej kolejności wpływa na określone wybory. Cyberpolaryzacja, która odpowiada polaryzacji w sieci, jest zjawiskiem realnym i prawdziwym. Dochodzi do niej w wyniku używania przekonujących argumentów i informacji przekazywanych podczas interakcji sieciowych. Drugim elementem wpływającym na zjawisko cyberpolaryzacji jest reputacja, wyznaczająca wartość jednostki w grupie. Trzecim natomiast jest korelacja cech: zaufania, ekstremizmu i potwierdzenia jako elementów występujących wspólnie w procesie oddziaływania na jednostkę. Jednostka, zyskując zaufanie, staje się bardziej ekstremalna w swoich przekonaniach, co nie musi prowadzić do radykalizmów, jednak stosując potwierdzanie (realizowane stwierdzeniem „ludzie tacy jak ty”), umacnia się w swoich przekonaniach, praktykach społecznych i komunikacyjnych. Cyberpolaryzacja prowadzi do powstawania enklaw deliberacji (enclave deliberation). Można je zdefiniować jako wyizolowane grupy, w których podobnie myślący ludzie komunikują się głównie między sobą. Media społecznościowe znacznie ułatwiają procesy kreacji enklaw deliberacji, jednocześnie obniżając koszty tworzenia takich sieciowych grup-enklaw (Sunstein 2018, s. 68-87).

Zagrożenie rosyjską wojną informacyjną jest przedmiotem wielu analiz koncentrujących się na propagandzie oraz dezinformacji i trollingu $u^{2}$. Za istotny obszar analizy przyjmuje się prowadzone przez rosyjskie służby specjalne działania, będące instrumentem kreowania lub intensyfikowania kryzysów politycznych. Polegają one na wzmacnianiu środowisk radykalnych, tendencji antyunijnych, aktywności

1 RT (do 2009 roku Russia Today) to rosyjska telewizja propagandowa, wyrażająca rosyjską rację stanu.

2 Trollowanie (ang. trolling) polega na celowym i intencjonalnym wpływaniu na innych użytkowników w celu ich ośmieszenia, obrażenia lub prowokowania konfliktów w sieciowych dyskursach. Prowadzi do tego publikowanie informacji nieprawdziwych (fake news), napastliwych, kontrowersyjnych lub obraźliwych wpisów, prowokujących do dyskusji. Aktywność trolli widoczna jest w sieci: na forach, w grupach społecznościowych oraz na czatach. Skutkiem trollingu jest dezorganizacja prowadzonej dyskusji, która zostaje podporządkowana interakcjom użytkowników wobec wpisów dokonywanych przez trolla. Trolling, jako zjawisko wykorzystywane w sieciowej propagandzie i dezinformacji, podlega instytucjonalizacji poprzez tworzenie tzw. farm trolli, wykorzystywanych do działań zmasowanych. Do usuwania kont obsługiwanych przez trolli, za pomocą których prowadzone są działania związane głównie z propagandą polityczną (w formie tzw. czarnej propagandy), przyznał się Facebook i Google [https://businessinsider.com.pl/technologie/ farma-trolli-na-facebooku-koncern-zablokowal-kolejne-konta/83hj94h; http://wyborcza. pl/7,155287,22492420,po-google-tez-hasaly-trolle-z-rosji.html; 8.08.2019]. 
dążących do zakłócania procesów politycznych oraz dyskredytacji nieprzychylnych Kremlowi środowisk i liderów politycznych ${ }^{3}$. W treści niniejszego artykułu skoncentrowano się na analizie sposobu relacjonowania protestów we Francji poprzez kreowanie w przestrzeni internetu ukierunkowanej narracji z wykorzystaniem rosyjskich mediów propagandowych. Badania zostały przeprowadzone w serwisach społecznościowych. Analizie poddano tworzenie i upowszechnianie treści przez rosyjskie media propagandowe: RT, Sputnik France (dalej Sputnik) i Ruptly. tv. Dokonując kategoryzacji tematycznej publikowanych informacji ze względu na ich treść oraz formy przekazu, zilustrowano zaangażowanie użytkowników w ruch sieciowy oraz wyrażanie opinii o wydarzeniach we Francji. Wnioski płynące $\mathrm{z}$ badań pozwalają na identyfikację założeń rosyjskiej propagandy pochodzących z oficjalnych dokumentów regulujących politykę informacyjną Federacji Rosyjskiej w praktycznym tworzeniu i rozprzestrzenianiu treści w przestrzeni sieciowej.

\section{Rewolucja „żóttych kamizelek”. Przyczyny jej wybuchu i przebieg wydarzeń}

Rewolucja „żółtych kamizelek” związana jest z ruchem społecznym, który rozwijał się od początku 2018 roku na Facebooku. Aktywiści ruchu „Gniew” (fr. Colère) artykułowali tam przesłanki, które następnie, jesienią 2018 roku, wykorzystane zostały w rewolucji „żółtych kamizelek” ( $f r$. le mouvement des gilets jaunes). Ruch powstał i aktywizował jednostki w sieci, co odpowiada współczesnej teorii tworzenia nowych ruchów społecznych (zob. Juris 2008; Castells 2013b, s. 27-28). „Gniew”, będąc typowym przykładem nowych ruchów społecznych, pozostał niesformalizowany, apolityczny, bez struktur organizacyjnych oraz jednolitych postulatów (Offe 2009, s. 219-222; Eisenstadt 2009, s. 11; Paleczny 2010, s. 24-28; Marczewska-Rytko 2017, s. 16-17; Piechota 2018, s. 32-42). W wyniku sformułowania problemów i ich masowego poparcia wyrażonego podpisaniem petycji w sieci ${ }^{4}$, doszło do przeniesienia protestu na ulice francuskich miast. Z czasem zwolennicy ruchu uaktywnili się również w Belgii, Holandii, Portugalii oraz Wielkiej Brytanii i Izraelu. Postulaty protestujących, mimo iż dotyczyły problemów istotnych lokalnie (tj. w miejscach protestu), zostały zdefiniowane ogólniej jako sprzeciw społeczny przeciwko decyzjom elit politycznych. Symbolem protestów stała się żółta kamizelka - obowiązkowe wyposażenie samochodów we Francji. Protesty na ulicach Paryża rozpoczęły się 17 listopada 2018 roku, bezpośrednio po drastycznym podniesieniu wysokości opodatkowania paliw. Wydarzenia we Francji (i w pozostałych wymienionych krajach), zdaniem Aurélie Lebelle, uznaje się za protesty klasy średniej, której warunki życia

3 W literaturze takie działania określa się mianem „środków aktywnych” i zalicza do operacji ofensywnych. Szerzej o tym zagadnieniu piszą m.in. J. Darczewska i P. Żochowski; P. Ogrodowczyk; F. Bryjka.

4 Do 25 października petycję podpisało 225 tys. osób, a do 10 grudnia 2018 petycja zebrała ponad 1,128 mln podpisów (Czarnacka 2018). 
obniżają się na skutek rosnących cen i kosztów utrzymania. Zaangażowali się w nie przede wszystkim mieszkańcy prowincji, dla których korzystanie z własnego samochodu jest wyznacznikiem jakości życia oraz daje możliwość wykonywania pracy.

\section{Znaczenie rosyjskich mediów propagandowych $w$ realizacji polityki informacyjnej Federacji Rosyjskiej}

Joanna Darczewska, analizując dokumenty strategiczne Federacji Rosyjskiej, zwraca uwagę na kompleksowe podejście do różnych aspektów działań informacyjnych, w tym z dziedziny cyberpower. Badaczka zauważa ciągłość podejścia strategicznego oraz trwałość mechanizmów realizacji strategicznych celów pozwalających na osiąganie zaplanowanych efektów. Podkreśla, że analiza działań „informacyjnych” pozwala sformułować wiosek „o swoistym dwójmyśleniu rosyjskich strategów, łączących podejście informacyjno-technologiczne z podejściem informacyjno-psychologicznym" (Darczewska 2016, s. 8).

Odwołując się do źródeł, tj. dokumentów regulujących politykę informacyjną Federacji Rosyjskiej, należy podkreślić, iż koncepcja aktywności Rosji w przestrzeni informacyjnej polega na działaniach związanych z kształtowaniem, tworzeniem, przekształcaniem i przekazywaniem informacji wpływających na świadomość indywidualną i społeczną ${ }^{5}$. Przestrzeń informacyjna jest płaszczyzną konfrontacji i prowadzenia walk informacyjnych w kontekście geograficznym, politycznym, ekonomicznym, społecznym i cywilizacyjnym. Doktryna bezpieczeństwa informacyjnego Federacji Rosyjskiej zawiera opracowanie mechanizmów kontroli, dzięki której kształtowane są odpowiednie, z punktu widzenia osiągania celów narodowych, wartości społeczne i duchowe obywateli Rosji. Do nich zalicza się: wychowanie młodych ludzi w duchu patriotyzmu i odpowiedzialności za kraj, dążenie do odrodzenia dziedzictwa kulturowego narodów i narodowości zamieszkujących Federację Rosyjską oraz wpływ na niekontrolowanie komercjalizacji kultury i nauki.

Działania prowadzone przez Rosjan przybierają charakter defensywny, gdy dotyczą obrony własnej integralności informacyjnej, bądź ofensywny, gdy ich celem jest "oddziaływanie, uszkadzanie i niszczenie systemu informacyjnego przeciwnika" (Darczewska 2016, s. 11). Działania defensywne to ochrona rosyjskiej przestrzeni informacyjnej przed konkurencyjnymi modelami rozwoju politycznego, ekonomicznego, a także kulturowego i społecznego. Cytowana autorka określa działania defensywne jako mające na celu ochronę rosyjskiego reżimu autorytarnego, jednocześnie zaznaczając, że od 2000 roku podmioty Federacji Rosyjskiej przygotowują się do prowadzenia konfliktów w przestrzeni informacyjnej (Darczewska 2016, s. 12). Badaczka pisze:

5 Концептуальные взгляды на деятельность Вооруженных Сил Российской Федерации в информационном пространстве [Кonceptualnyje wzglady na diejatielnost' Woorużennych Sił Rossijskoj Fiedieracii w informacjonnom prostranstwie] [http://ens.mil.ru/science/ publications/more.htm?id=10845074@cmsArticle; 3.04.2019]. 
Rosyjskie dokumenty strategiczne są inicjowane odgórnie, co znajduje wyraz w stosownych dekretach prezydenta Putina ${ }^{6}$. Są elementem szerszej strategii informacyjnej Kremla i mają konkretnych adresatów, zarówno wewnętrznych jak i zewnętrznych. Antyzachodnia retoryka jest wykorzystywana jako środek w polityce wewnętrznej. W przeszłości retoryka budowała zapotrzebowanie obywateli na silne państwo cieszące się autorytetem na arenie międzynarodowej, obecnie buduje gotowość mobilizacyjną społeczeństwa, umacniając poczucie zagrożenia ze strony Zachodu (Darczewska 2016, s. 19).

Drugim odbiorcą jest opinia publiczna w krajach Wspólnoty Niepodległych Państw. Jej pozyskanie ma ułatwić realizację geopolitycznych celów Kremla, takich jak: utrzymanie wpływów na obszarze byłego ZSRR czy zapobieganie integracji państw postradzieckich z Zachodem. Oba te wymiary, wewnętrzny i regionalny, są ściśle ze sobą splecione co umożliwia koncepcja świata eurazjatyckiego. W rezultacie obrona przed tzw. czwartym zagrożeniem (tj. wynikającym z obcych wpływów kulturowych) jest przedstawiana jako obrona wspólnoty cywilizacyjnej przed wtargnięciem obcego kodu kulturowego. Stosuje się przy tym typ narracji budowanej na antagonizowaniu grup społecznych, zgodnie z modelem: „swój-obcy”. Walkę o uzyskanie przewagi informacyjnej Federacja Rosyjska rozgrywa, przeciwstawiając ideologicznie tradycyjne i konserwatywne wartości liberalizmowi, który charakteryzuje indywidualizm, technokracja oraz globalizm. Jak twierdzi Darczewska „Rosja nie jest i nie będzie potęgą proliberalną. Jest postliberalną siłą rewolucyjną, walczącą o sprawiedliwy świat wielobiegunowy, prawdziwą godność i wolność. W swojej wojnie z liberalizmem Rosja deklaruje bronić tradycji, wartości konserwatywnych i prawdziwej wolności” (Darczewska 2014, s. 18-19).

Ochrona jednolitej przestrzeni informacyjnej Federacji Rosyjskiej, jak również prowadzenie działań ofensywnych, toczy się przy udziale mediów propagandowych, do których zaliczyć należy agencję medialną Sputnik, telewizję RT oraz podporządkowaną jej stację o charakterze dokumentacyjnym - Ruptly.tv. Robert Rajczyk, dokonując typologii mediów propagandowych, uznaje wspomniane wyżej trzy kanały, których dysponentem są władze Federacji Rosyjskiej, za „propagandowe media narracyjne” (Rajczyk 2016, s. 75) ${ }^{7}$. Cechą charakterystyczną tego typu mediów jest pozorny obiektywizm oraz prezentowanie wizji świata z punktu widzenia ich

6 „W tym kontekście można przytoczyć ujawnioną w części Koncepcję państwowego systemu wykrywania, uprzedzania i likwidacji skutków ataków komputerowych z 12 grudnia 2014 roku (Nr K 1274), a opracowaną na podstawie stosownego dekretu prezydenta Władimira Putina z 15 stycznia 2013 roku o stworzeniu państwowego systemu monitoringu, uprzedzania i likwidacji skutków ataków komputerowych na zasoby informacyjne Federacji Rosyjskiej. $\mathrm{Na}$ marginesie: instytucjonalnym koordynatorem systemu centrów terytorialnych jest Federalna Służba Bezpieczeństwa, wiadomo także, że poszczególne części systemu, w tym Siły Zbrojne Federacji Rosyjskiej, mogą tworzyć własne centra, które pozostają w sferze ich wyłącznej odpowiedzialności" (Darczewska 2016, s. 19).

7 W niniejszym artykule na określenie badanych kanałów używam zamiennie pojęć rosyjskie media propagandowe i rosyjskie media narracyjne. 
dysponenta. Jak wyraźnie podkreśla Rajczyk, media prowadzące narrację propagandową pozycjonują się w warunkach obiektywizmu dziennikarskiego. Jednak analiza dystrybuowanych przez nie treści (w szczególności autor zwraca uwagę na warstwę językową oraz agenda setting), determinuje zawartość przekazów z uwzględnieniem problematyki wrażliwej zarówno dla dysponenta mediów, jak i służącej osiąganiu pożądanych celów (Rajczyk 2016, s. 75).

Telewizja RT określa się jako medium dostarczające informacji pomijanych przez media głównego nurtu i prezentujące alternatywną perspektywę interpretacji wydarzeń światowych, uwzględniając rosyjski punkt widzenia. Ruptly.tv to międzynarodowa agencja informacyjna działająca na rynku od 2013 roku. Swoją rolę definiuje jako prezentowanie odważniejszego i pogłębionego spojrzenia na rzeczywistość. Kieruje się perspektywicznością oraz oferuje wiadomości bez cenzury ${ }^{8}$. Agencja informacyjna Sputnik powstała w 2014 roku. Została założona przez agencję Rossija siegodnia dekretem prezydenta Putina. Sputnik dostarcza treści w ponad trzydziestu językach, jest obecny m.in. w Stanach Zjednoczonych (Waszyngton, DC), w Chinach (Pekin), we Francji (Paryż), w Niemczech (Berlin). Misją Sputnika jest „naświetlanie wydarzeń światowej polityki oraz gospodarki” oraz „zorientowanie na zagraniczne audytorium"9.

Darczewska, porządkując działania zgodnie z wykorzystaniem w nich przez rosyjskie służby specjalne technologii hybrydowych, wskazała trzy typy propagandy politycznej.

Tabela 1. Współczesny aparat technologii hybrydowych przyjętych w Federacji Rosyjskiej

\begin{tabular}{|c|c|}
\hline Rodzaj technologii hybrydowych & Przedsięwzięcia organizacyjne \\
\hline $\begin{array}{l}\text { CZARNE (koordynowane } \\
\text { przez służby wywiadowcze) }\end{array}$ & $\begin{array}{l}\text { - pozyskiwanie agentury wpływu oraz instrumentalizowanie } \\
\text { do realizacji celów Rosji osób tego nieświadomych } \\
\text { - skrytobójstwa i terroryzm } \\
\text { - fabrykowanie dowodów (fałszywe dokumenty, fejki) } \\
\text { - grupy pozorowane do przeprowadzania aktów prowokacji, } \\
\text { np. dewastacja pomników i miejsc pamięci } \\
\text { - akcje quasi-militarne: dywersja i niejawne ograniczone stosowanie } \\
\text { przemocy } \\
\text { - inspirowanie demonstracji i zamieszek } \\
\text { - przekupywanie, korumpowanie i szantażowanie polityków } \\
\text { - tworzenie fałszywych kont i sieci botów do prowadzenia ataków } \\
\text { cybernetycznych, propagandy } 2.0 \text { i organizowania cyberprotestów }\end{array}$ \\
\hline
\end{tabular}

8 [https://ruptly.tv/en/about-ruptly; 6.04.2019].

9 [https://pl.sputniknews.com/docs/about/index.html;15.05.2019]. 


\begin{tabular}{|c|c|}
\hline Rodzaj technologii hybrydowych & Przedsięwzięcia organizacyjne \\
\hline SZARE (koordynowane przez Kreml) & $\begin{array}{l}\text { - instrumentalizowanie oraz inspirowanie różnych grup } \\
\text { społecznych, w tym partii i organizacji skrajnych } \\
\text { - działania za pośrednictwem rosyjskiego sektora pozarządowego } \\
\text { i kontrolowanych organizacji międzynarodowych } \\
\text { - instrumentalizowanie rosyjskich fundacji i stowarzyszeń, } \\
\text { np. Russkij Mir, Rosyjskie Towarzystwo Historyczne } \\
\text { - zakładanie prorosyjskich portali oraz ich wspieranie finansowe } \\
\text { - zakładanie fabryk trolli i organizowanie prokremlowskich sieci } \\
\text { - dokonywanie ataków społecznościowych, trolling }\end{array}$ \\
\hline BIAŁE (koordynowane przez Kreml) & $\begin{array}{l}\text { - akcje propagandowe prowadzone za pośrednictwem } \\
\text { multimedialnych państwowych agencji informacyjnych } \\
\text { (TV RT, Radio Sputnik, RIA Novosti) } \\
\text { - przedsięwzięcia realizowane za pośrednictwem oddziałów } \\
\text { Rossodrużestwa, RONIK-ów (rosyjskie ośrodki nauki i kultury) } \\
\text { przy ambasadach Federacji Rosyjskiej, innych organów władzy } \\
\text { wykonawczej i ustawodawczej (np. Komisji do Spraw Obrony } \\
\text { Suwerenności FR przy Radzie Federacji), } \\
\text { - organizowanie wydarzeń o charakterze naukowym i kulturalnym } \\
\text { (konferencje, wystawy, rajdy pamięci, stypendia i kursy językowe) }\end{array}$ \\
\hline
\end{tabular}

Źródło: Darczewska 2018, s. 60.

Tabela 1 odwołuje się do istniejącego $\mathrm{w}$ teorii propagandy politycznej podziału na propagandę białą, szarą i czarną. Działania, jakie podejmują rosyjskie media propagandowe, mieszczą się $\mathrm{w}$ aktywnościach przypisanych propagandzie białej. Jej istota polega na budowaniu wiarygodności nadawcy, który jawnie prezentuje swoje przekonania ideologiczne. $\mathrm{W}$ tym rozumieniu działania podejmowane przez Federację Rosyjską, wykorzystującą własne media propagandowe, należy traktować jako pełniące dwie funkcje. Pierwsza to funkcja informacyjno-interpretacyjna: treści łączą elementy informacji i interpretacji, tworząc przekaz perswazyjny służący do budowania efektywnego oddziaływania propagandowego. Druga to funkcja integracyjna, której celem jest stabilizacja systemu polityczno-społecznego (przyjętego w Federacji Rosyjskiej) na fundamencie kultury narodu i podzielanych wartości społecznych.

\section{Relacjonowanie protestów „żóltych kamizelek” przez rosyjskie media propagandowe. Metodologia i wyniki badań}

\section{Metodologia badań}

Rozważania zawarte w artykule oparto na dwóch teoriach kształtujących postrzeganie procesów komunikowania związanych z protestami politycznymi w kontekście międzynarodowym: teorii transnarodowych przestrzeni dyskursywnych oraz teorii agenda setting. Teoria transnarodowych przestrzeni dyskursywnych opiera się na dwóch istotnych filarach. Pierwszym z nich jest przyjęcie, że istnieje globalna przestrzeń publiczna, w której powstają przestrzenie dyskursywne. Drugim zaś założenie, iż geograficzną ekspansję transnarodowej opinii publicznej wywołują 
media, w ostatnich latach przede wszystkim social media. Teoria transnarodowych przestrzeni dyskursywnych stanowi rozwinięcie teorii przestrzeni publicznej Jürgena Habermasa (Habermas 1989, s. 73-74), zakładającej, że przestrzeń publiczną charakteryzują: swobodny dostęp obywateli oraz korzystanie przez nich z przysługujących im praw, w tym z możliwości zgromadzeń i wolnego wyrażania opinii. Media społecznościowe traktowane są jako płaszczyzna dyskursu dostępna dla każdego, kto chciałby tam komentować kwestie istotne z punktu widzenia własnych potrzeb, przy jednoczesnym przyjęciu istotności zagadnień dla wspólnoty. W procesie dyskursu sformułowana jest opinia publiczna, która dzięki potencjalnemu zasięgowi może mieć charakter globalny. Jak twierdzi Denis McQuail, komunikacja międzynarodowa prowadzona z wykorzystaniem mediów społecznościowych staje się czynnikiem sprzyjającym tworzeniu transnarodowej areny dyskursu opinii publicznej (McQuail 2009). Podobnie uważa Ingrid Volkmer, twierdząc, że globalna komunikacja zmieniła orientację opinii publicznej, która przestała być wyłącznie elementem systemu politycznego społeczeństwa, stała się natomiast autonomiczną globalną sferą publiczną istniejącą między państwem a globalną społecznością (Volkmer 1999, s. 119). Prowadzi to do konstatacji, iż obecnie opinia publiczna może mieć charakter transnarodowy, w jej przestrzeni odbywa się dyskusja o kwestiach istotnych z globalnego punktu widzenia (Volkmer 2014). Ustalając tematykę ważną dla opinii publicznej, należy odwołać się do teorii agenda setting, zakładającej, że to media informacyjne, głównie poprzez proces filtrowania faktów, kreują obraz rzeczywistości. Media, przekazując wybrane przez siebie informacje, wpływają na to, co staje się przedmiotem dyskursu w opinii publicznej. Wskazując na istotność tematów, środki masowego przekazu posiadają zdolność ustalania hierarchii tematów ważnych, które kształtują opinię publiczną i prowadzony w jej przestrzeni dyskurs. Jak twierdzi Floribert Patrick Endong, w erze cyfrowej to media społecznościowe odgrywają znacznie istotniejszą rolę niż media tradycyjne (Endong 2018, s. 39). Zarówno dziennikarze, aktywiści, jak i użytkownicy mediów społecznościowych, takich jak Twitter i Facebook, wpływają na kształtowanie agenda setting. Teoria agenda setting $\mathrm{w}$ związku $\mathrm{z}$ rozwojem mediów internetowych podlega modyfikacji, wykształcając nowe modele poszerzające rozumienie zmian zachodzących $w$ świecie, $\mathrm{z}$ jednoczesnym uwzględnieniem nowych form komunikowania (McCombs i in. 2014, s. 783). Wśród nowych modeli agenda setting znalazł się sieciowy model ustanawiania agendy (network agenda-setting model). Określa on możliwość narzucania opinii publicznej przez media społecznościowe takich interpretacji widzenia świata, jakie wynikają ze zdolności wzmacniania efektu i wykorzystania emocjonalnych atrybutów odpowiadających preferencjom odbiorców (Weiman, Brosius 2016, s. 27-29). Ewa Nowak uważa, iż zgodnie z sieciowym modelem ustanawiania agendy (network agenda-setting model) dochodzi nie tylko do przenoszenia $\mathrm{z}$ agendy medialnej do publicznej ważności zagadnień $i$ jej atrybutów, ale także „zespołów atrybutów, powiązanych atrybutów i kwestii" (Nowak 2016, s. 15). Nowak twierdzi, że wynikający ze zmodyfikowanej teorii agenda setting model prowadzi do wykształcania się nowych typów agendy, poszerzających rozumienie zachodzących na świecie procesów przy jednoczesnym 
uwzględnianiu internetowych form komunikowania. Agenda świata rzeczywistego (real world agenda $)^{\mathbf{1 0}}$ obejmuje uznane za istotne problemy wynikające $\mathrm{z}$ otaczającej rzeczywistości. Źródłem odwołania w modelu są sprawy ekonomiczne i społeczne, takie jak ubóstwo, bezrobocie, niesprawiedliwy podział dóbr, zmiany klimatu. Do tego typu agendy zalicza się również relacje pomiędzy problemami świata a rolą elit politycznych $w$ ich rozwiązywaniu.

Przyjmując zatem, że oddziałujące na transnarodowy dyskurs media społecznościowe kształtują agenda setting w efekcie aktywności online użytkowników, w badaniach założono, że kreują one transnarodową przestrzeń dyskursywną podczas protestów politycznych poprzez udostępnianie płaszczyzny dla globalnego transferu informacji o protestach oraz upowszechnianie treści w wymiarze ponadnarodowym.

Celem przeprowadzonych badań było ustalenie, w jaki sposób, z wykorzystaniem agendy świata rzeczywistego, rosyjskie media propagandowe opowiedziały historię, używając w tym celu mediów społecznościowych, które jednocześnie utworzyły enklawy deliberacji. Dzięki transferowi treści opowiadających określony typ historii media społecznościowe są używane jako narzędzie cyberpolaryzacji umożliwiającej osiąganie celów propagandowych.

- Hipoteza 1. Relacjonowanie przebiegu rewolucji „żółtych kamizelek” przez rosyjskie globalne kanały medialne (RT, Sputnik i Ruptly.tv) z wykorzystaniem ich serwisów społecznościowych zostało wpisane w osiąganie celów propagandowych przez Federację Rosyjską. Cele wynikały z poszerzenia widzialności świata zewnętrznego pomijanego przez zachodnioeuropejskie media tradycyjne.

- Hipoteza 2. Liczba relacjonowanych informacji dzięki aktywności użytkowników pozwoliła na transmisję obrazu świata zachodniego w sposób korzystny propagandowo i zgodny z zamierzeniami nadawcy treści.

W celu potwierdzenia lub obalenia przyjętych hipotez sformułowano następujące pytania badawcze:

- RQ1. W jaki sposób kanalizowanie relacjonowania wydarzeń podczas rewolucji „żółtych kamizelek” wpłynęło na ukształtowanie opowieści służącej osiąganiu rosyjskich celów propagandowych?

- RQ2. W jaki sposób liczba opublikowanych informacji oraz uzyskane zasięgi sieciowe pozwoliły nadawcy na osiągnięcie celów propagandowych?

10 Nowak definiuje ten model następująco: „real world agenda - nowe media sprawiają, że zakres "wycinania agendy", a tym samym pomijania istotnych kwestii przez media informacyjne, jest mniejszy niż dotychczas - szerszy zakres widoczności świata rzeczywistego w mediach daje szansę na powstanie wpływu mediów w odniesieniu do większej liczby kwestii; należy jednak również brać pod uwagę fakt, że to media społecznościowe sygnalizują istnienie problemów «wycinanych» przez media tradycyjne i w tym kontekście wpływ mediów tradycyjnych na opinię publiczną jest słabszy" (Nowak 2016, s. 23). 
Badania przeprowadzono metodą ilościowo-jakościową. Dokonano pomiaru liczby opublikowanych treści w dwóch serwisach społecznościowych (Twitter i YouTube) ${ }^{11}$ wraz z pomiarem zasięgów, jakie wygenerowały poszczególne treści. Ponadto treści poddano analizie jakościowej. Fakt ten umożliwił dokonanie klasyfikacji tematycznej zamieszczanych informacji oraz umożliwił wskazanie form ich przekazu, istotnych z uwagi na zastosowane kanały transmisji. Po przeprowadzeniu analizy treści opublikowanych materiałów wyodrębniono pięć kategorii tematycznych, do których na zasadzie wyłączności przypisano każdy z materiałów, tj.:

1. Relacje z protestów - informacje prezentujące przebieg wydarzeń;

2. Zwiększanie zasięgu protestów - multiplikowanie informacji najczęściej poprzez udostępnienie w kanale RT materiałów wcześniej opublikowanych w kanale Ruptly.tv;

3. Brutalność policji - relacjonowanie działań policji wobec obywateli;

4. Naruszanie praw człowieka - materiały prezentujące naruszanie przez policję nietykalności osobistej protestujących, ilustrowanie skutków agresji policji;

5. Inne - tematy niezwiązane $\mathrm{z}$ żadną z powyższych kategorii.

Analizą objęto okres od wybuchu protestów na ulicach francuskich miast (tj. od dnia 17 listopada 2018 roku) do 16 marca 2019 roku, kiedy rozpoczęto realizację badań. Analizie poddane zostały treści zamieszczone w serwisie Twitter (badano treści ze znacznikiem YellowVest i jego francuskim odpowiednikiem - GiletJaune) oraz na oficjalnym kanale protestujących „Gilet Jaune Yellow News” (we francuskich kanałach treści rosyjskich mediów gościły sporadycznie). Na kanale YouTube dokonano selekcji treści, posługując się hasłem w wyszukiwarce „YellowVest”, natomiast analizie poddano wyłącznie te materiały filmowe, które dodane były przez rosyjskie media propagandowe.

\section{Wyniki badań}

W trzech tabelach (2-4) wskazano aktywność każdego z rosyjskich mediów propagandowych w kanale YouTube, ujawniając sumę opublikowanych treści oraz wygenerowany ruch przez użytkowników sieciowych.

Tabela 2. Zawartość w serwisie YouTube materiałów telewizji RT

\begin{tabular}{l|c|c|c|c|c}
\hline & \multicolumn{1}{c}{$\begin{array}{c}\text { Relacje } \\
\text { z protestów }\end{array}$} & $\begin{array}{c}\text { Zwiększanie } \\
\text { zasięgu } \\
\text { protestów }\end{array}$ & $\begin{array}{c}\text { Brutalność } \\
\text { policji }\end{array}$ & $\begin{array}{c}\text { Naruszanie } \\
\text { praw człowieka }\end{array}$ & Inne \\
\hline $\begin{array}{l}\text { Liczba } \\
\text { opublikowanych } \\
\text { filmów }\end{array}$ & 35 & 6 & 9 & 6 & 6 \\
\hline Liczba wyświetleń & 2639604695 & 560606 & 628455 & 220806 & 899337 \\
\hline Liczba lubiących & 43246 & 10068 & 11526 & 3641 & 12807 \\
\hline
\end{tabular}

11 Te serwisy były podstawowymi kanałami transmisji informacji o protestach. 


\begin{tabular}{lccccc} 
& $\begin{array}{c}\text { Relacje } \\
\text { z protestów }\end{array}$ & $\begin{array}{c}\text { Zwiększanie } \\
\text { zasięgu } \\
\text { protestów }\end{array}$ & $\begin{array}{c}\text { Brutalność } \\
\text { policji }\end{array}$ & $\begin{array}{c}\text { Naruszanie } \\
\text { praw człowieka }\end{array}$ & Inne \\
\hline $\begin{array}{l}\text { Liczba } \\
\text { komentujących }\end{array}$ & 8957 & 4324 & 3278 & 1547 & 2057
\end{tabular}

Źródło: opracowanie własne.

Tabela 3. Zawartość w serwisie YouTube materiałów telewizji Ruptly.tv.*

\begin{tabular}{|c|c|c|c|c|c|}
\hline & $\begin{array}{c}\text { Relacje } \\
\text { z protestów }\end{array}$ & $\begin{array}{c}\text { Zwiększanie } \\
\text { zasięgu } \\
\text { protestów }\end{array}$ & $\begin{array}{c}\text { Brutalność } \\
\text { policji }\end{array}$ & $\begin{array}{c}\text { Naruszanie } \\
\text { praw czlowieka }\end{array}$ & Inne \\
\hline $\begin{array}{l}\text { Liczba } \\
\text { opublikowanych } \\
\text { filmów }\end{array}$ & 28 & 11 & 8 & 3 & 1 \\
\hline Liczba wyświetleń & 3715893 & 233154 & 147748 & 38873 & 4822 \\
\hline
\end{tabular}

Źródło: opracowanie własne.

* wyłączona możliwość komentowania, badaniu podlegały wyłącznie zasięgi

Tabela 4. Zawartość w serwisie YouTube materiałów agencji Sputnik*

\begin{tabular}{c|c}
\hline & Relacje z protestów \\
\hline Liczba opublikowanych filmów & 2 \\
\hline Liczba wyświetleń & 54977 \\
\hline Liczba lubiących & 1094 \\
\hline Liczba komentujących & 100
\end{tabular}

Źródło: opracowanie własne.

${ }^{*} \mathrm{w}$ serwisie Sputnik w badanym okresie ukazały się wyłącznie dwa filmy będące relacjami z protestów

Wśród publikowanych treści dominowały te prezentujące przebieg wydarzeń. Każdy z nadawców przekazywał przede wszystkim komunikaty, które w sposób organiczny generowały ruch sieciowy, wpływając na zwiększanie zasięgów i generując aktywność internautów. Materiały filmowe udostępniane na kanale YouTube były zwykle pozbawione komentarza, a czas trwania relacji był zróżnicowany (zdarzały się całodniowe relacje z protestów).

Wykorzystanie YouTube’a przez rosyjskie media propagandowe można uznać za próbę utylitarnego podejścia do serwisu. YouTube uznawany jest za źródło wiarygodnej informacji, niepoddawanej edycji i obróbkom. To kanał najczęściej używany przez aktywistów, ale również przez zwykłych uczestników protestów, będący przestrzenią transferu prodemokratycznych treści (Majorek 2015, s. 20; Piechota, Rajczyk 2015; Piechota 2018, s. 117-118). Paul Levinson, określając serwis YouTube „obrońcą demokracji” (Levinson 2010, s. 108), zaznaczył, iż relacje 
online pozwalają na rozprzestrzenianie faktów i uruchamiają kolejne wydarzenia. Rosyjskie media propagandowe, korzystając z YouTube'a, nadały publikowanym treściom walor wiarygodności. Serwis wykorzystywano podczas przesileń politycznych, jak również zamieszczano tam filmy niepoddawane edycji i generujące organiczny ruch użytkowników.

Tabela 5. Zawartość serwisu społecznościowego Twitter

(\#YellowVest). Formy przekazu i generowane zasięgi

\begin{tabular}{c|c|c|c}
\hline $\begin{array}{c}\text { Forma przekazu/ } \\
\text { zasięgi - retweety }\end{array}$ & Zdjęcia & Filmy & $\begin{array}{c}\text { Materiały } \\
\text { dziennikarskie } \\
\text { pochodzące z serwisu } \\
\text { internetowego }\end{array}$ \\
\hline RT & $11 / 895$ & $33 / 4558$ & $11 / 960$ \\
\hline Ruptly & $5 / 246$ & $19 / 5813$ & 0 \\
\hline Sputnik & $5 / 168$ & $1 / 35$ & 0 \\
& Źródło: opracowanie własne. &
\end{tabular}

Tabela 6. Zawartość serwisu społecznościowego Twitter (\#YellowVest). Rodzaj relacji i generowany ruch użytkowników

\begin{tabular}{c|c|c|c|c|c}
\hline $\begin{array}{c}\text { Ogólna } \\
\text { liczba postów } \\
\text { z RT, Ruptly } \\
\text { oraz Sputnika }\end{array}$ & $\begin{array}{c}\text { Relacje } \\
\text { z protestów }\end{array}$ & $\begin{array}{c}\text { Zwiększanie } \\
\text { zasięgu } \\
\text { protestów }\end{array}$ & $\begin{array}{c}\text { Brutalność } \\
\text { policji }\end{array}$ & $\begin{array}{c}\text { Naruszanie } \\
\text { praw człowieka }\end{array}$ & Inne \\
\hline $\begin{array}{c}\text { Liczba } \\
\text { opublikowanych } \\
\text { treści }\end{array}$ & 37 & 8 & 21 & 12 & 7 \\
\hline $\begin{array}{c}\text { Liczba retwittów } \\
\text { Liczba lubiących }\end{array}$ & 134911 & 1362 & 5111 & 1239 & 982 \\
\hline
\end{tabular}

Tabele 5 i 6 ilustrują aktywność rosyjskich mediów propagandowych w serwisie Twitter. Dokonując kategoryzacji materiałów (tabela 6), wykorzystano te same kategorie, które przypisano treściom w serwisie YouTube. Natomiast w tabeli 5 dokonano podziału treści z uwzględnieniem form ich przekazu. Analiza zawartości przedstawionych w tabeli 5 potwierdza, iż podobnie jak w przypadku informacji w serwisie YouTube, opublikowane na Twitterze treści najczęściej przybierały formę filmów, co jednocześnie generowało największy ruch wśród użytkowników. Mniejszym zainteresowaniem cieszyły się zdjęcia będące zwykle jednostkową, interesującą klatką filmową albo memy, które powstały na bazie wykorzystanych zdjęć. Na Twitterze, w porównaniu z zawartością w YouTube, częściej zamieszczano treści eksponujące skutki brutalności francuskiej policji podczas tłumienia zamieszek. Dzięki materiałom filmowym i za pomocą memów dokonano transferu przekazu potwierdzającego tezę o „zgniliźnie zachodniej kultury”, o radykalizmie 
protestujących oraz o bezsilności francuskiej władzy. Jak twierdzi Leszek Sykulski „jednym z najważniejszych celów działań rozproszonych jest doprowadzenie do głębokiego kryzysu we wrogim społeczeństwie i swego rodzaju kontrolowanego chaosu. Konflikt z wydarzenia staje się długotrwałym procesem" (Sykulski, 2019, s. 108). Autor uważa, że działania rozproszone mogą być prowadzone w różny sposób: przez głoszenie określonych poglądów, tworzenie ośrodków opiniotwórczych, wywoływanie napięć społecznych (emocjonalnych i fizycznych), poprzez działalność sabotażową i dywersyjną (Sykulski 2019, s. 108). Znaczenie rosyjskich mediów propagandowych, uznanych za narzędzie realizacji konfliktu dyfuzyjnego, przejawia się w utrzymywaniu napięcia społecznego oraz w nadawaniu znaczenia wydarzeniom w międzynarodowym dyskursie publicznym. Działania te opierają się na zaangażowaniu społeczności sieciowej jako głównego aktora zainteresowanego i jednocześnie zaangażowanego w wydarzenia. Sykulski podkreśla:

W dobie przenoszenia się znacznej części debaty publicznej do internetu następuje poszerzenie przestrzeni walki. Środowisko wirtualnej rzeczywistości staje się swego rodzaju „ekstra territorium”. Wojna dyfuzyjna stawia cywilów w centrum konfliktu, odwrotnie niż w standardowej wojnie, gdzie wojsko własne jest skierowane przeciwko wrogim siłom zbrojnym (Sykulski 2019, s. 110).

Materiały publikowane przez rosyjskie media propagandowe pełniły określone funkcje $w$ realizacji polityki zewnętrznej: utrzymywanie napięcia $\mathrm{w}$ jednym $\mathrm{z}$ ważnych państw-członków UE, polaryzowanie tamtejszego społeczeństwa i zwiększanie mobilizacji społecznej dzięki generowanym zasięgom. To wpływało na radykalizację wydarzeń, doprowadzając do uruchamiania nowych ośrodków protestów w innych miastach Francji oraz poza jej granicami. Jednocześnie zamieszczane informacje miały za zadanie wywarcie wpływu na politykę wewnętrzną. Dzięki publikowaniu treści mających charakter konsolidujący społeczeństwo wokół wartości, idei i systemu politycznego odwołującego się do modelu narracji, w którym Rosja jest depozytariuszem wartości tradycyjnych i lokujących ją w opozycji do „zgnilizny zachodniej", wpływano na społeczeństwo Federacji Rosyjskiej. Według Iana Kershawa (1983, s. 203) należy zwrócić uwagę na zależność pomiędzy efektywnością oddziaływania propagandy a funkcjonującymi stereotypami. Konfrontując tradycyjne i konserwatywne społeczeństwo rosyjskie z przekazami o powodach protestów społeczeństw zachodnich z jednoczesną prezentacją bezsilnej i pozbawionej autorytetu francuskiej władzy, rosyjskie media propagandowe potwierdziły skuteczność polityki wewnętrznej realizowanej w Federacji Rosyjskiej. Dzięki intensyfikacji relacji z protestów, a także wyborowi formy przekazów obywatele mogli obserwować, jak Francuzi walczą o godne życie, ich władze zaś, nadużywając działań policji, pozostawały bezsilne wobec postulatów protestujących. Nadając sens sytuacjom społecznym, doszło do wykorzystania schematu interpretacji rzeczywistości, która wywołała określone reakcje emocjonalne, co, jak twierdzi Castells, samo z siebie już stanowi przekaz informacji (Castells 2013a, s. 159). Działania komunikacyjne prowadzone przez rosyjskie media propagandowe należy uznać za świadome i celowe 
profilowanie informacji z uwzględnieniem ich potencjału przyciągania innych. Intensyfikując działania informacyjne prezentujące skalę zjawiska, zbudowano narrację o wydarzeniach wywołującą nacechowane emocjonalnie reakcje, których źródłem były uprzedzenia i stereotypy wynikające z podziału na „my i oni”. Teresa Sádaba uważa, że media społecznościowe są narzędziem, dzięki któremu dochodzi do rozprzestrzeniania ideologii w celu pozyskania nowych zwolenników (Sádaba 2006, s. 127-132). To odbywa się za pomocą wykorzystywania symboli, wartości kulturowych czy odwołań do narracji o charakterze historycznym. Wpisując działania prowadzone przez rosyjskie media propagandowe do modelu real world agenda, można przyjąć, że nadawcy treści propagandowych wykorzystali wydarzenia poruszające i integrujące opinię publiczną $\mathrm{w}$ skali międzynarodowej poprzez odwołanie się do powszechnie podzielanych wartości, takich jak prawa człowieka, w tym zwłaszcza prawo do godnego życia i manifestowania.

\section{Wnioski}

Zrealizowane badania pokazały, w jaki sposób rosyjskie media propagandowe relacjonowały wydarzenia francuskiej rewolucji „żółtych kamizelek”. Budując określoną narrację i wspomagając jej wiarygodność wyborem form upowszechnianych treści, w których dominowały filmy, rosyjskie media propagandowe zrealizowały działania służące nadawcy propagandy. Poprzez intensywność relacjonowania wydarzeń istotnych $\mathrm{w}$ agendzie świata rzeczywistego wykreowano alternatywną sieciową płaszczyznę dyskursu o wydarzeniach, przyczyniając się tym samym do osiągnięcia celów propagandowych ${ }^{12}$. Wśród komentarzy w serwisie YouTube pojawiły się opinie, że prawdę o protestach przekazuje rosyjska telewizja. W dyskursie, jaki powstał w serwisie YouTube, pod relacjami udostępnianymi przez RT znalazły się komentarze wskazujące, że użytkownicy odnotowali, iż to RT jako jedyna telewizja relacjonowała protesty i wydarzenia im towarzyszące. Cass R. Sunstein podkreśla, że niejednorodne społeczeństwo korzysta ze wspólnych doświadczeń informacyjnych, z których wiele jest produkowanych przez media (Sunstein 2018, s. 155). Te wspólne doświadczenia stanowią rodzaj kleju, ułatwiając wysiłki zmierzające do rozwiązania wspólnych problemów, zachęcając ludzi do wzajemnego oglądania się i współtworzenia, a czasem pomagając zapewnić reakcję na prawdziwe problemy i potrzeby, a nawet pomóc $w$ ich identyfikacji.

Badania potwierdziły obie przyjęte w niniejszym artykule hipotezy. Odwołując się do tematyki pomijanej przez zachodnie media mainstreamowe oraz wykorzystując kanały w mediach społecznościowych (z których zwykle korzystają aktywiści podczas protestów i formy przekazu w postaci filmów), wytworzono wrażenie,

12 Pojęciem „media alternatywne”, które tworzą alternatywną (sieciową) płaszczyznę do dyskusji, posługują się m.in. O.G. Bailey, B. Cammaerts i N. Carpentier, a także L.A. Lievrouw. Pojęcie to jednocześnie definiuje nowe media, w szczególności media społecznościowe będące alternatywą dla mediów mainstreamowych. 
iż rosyjskie media propagandowe prezentują wydarzenia istotne z punktu widzenia obywatelskiego, pomijane przez media głównego nurtu. Cele rosyjskiej propagandy zostały zrealizowane dzięki intensywnemu relacjonowaniu protestów i wydarzeń im towarzyszących, a zwiększanie zasięgów w sieci potwierdziło narrację nadawcy działań propagandowych. Teza ta potwierdza słowa Adama Lelonka, iż celem działań rosyjskiej propagandy jest utrzymywanie silnej polaryzacji społecznej, za której sprawą łatwiejsze jest wprowadzanie zamętu i przekonywanie własnego społeczeństwa co do słuszności realizowanej polityki. Sunstein uważa, że w odniesieniu do polaryzacji ważne jest postrzeganie tożsamości i przynależności do grupy, zwłaszcza w mediach społecznościowych (Sunstein 2018, s. 75). Polaryzacja grupy rośnie, jeśli ludzie myślą o sobie jako o grupie z istniejącą wspólną tożsamością i pewnym stopniem solidarności. Jeśli myślą o sobie w ten sposób, polaryzacja grupowa jest zarówno bardziej prawdopodobna, jak i bardziej ekstremalna. Podobną tezę głosi Clint Watts, twierdząc, iż media społecznościowe wzmacniają stronniczość dzięki liczbie ocenianych treści (Watts 2018, s. 217). Doceniając rolę integracyjną mediów społecznościowych, upowszechnieniu ulega naśladownictwo, powszechne jest zaufanie do informacji dostarczanych przez członków własnej grupy (im ufamy bardziej niż informacjom przekazywanym przez grupę zewnętrzną). Użytkownicy ufają nadawcy i przesyłanym informacjom niezależnie od tego, czy są one dokładne, czy nie. Współdziałanie z użytkownikami mediów społecznościowych w ramach przynależności do cyfrowego plemienia powoduje zanikanie indywidualnej opinii na rzecz najsilniejszych głosów, jakie są reprezentowane w grupie. To zaś skutkuje myśleniem grupowym, blokując alternatywne spojrzenie na nowe informacje.

Reasumując, sposób narracji przyjęty przez rosyjskie media propagandowe relacjonujące rewolucję „żółtych kamizelek” dzięki intensywności przekazów oraz wykorzystaniu form sieciowego uczestnictwa używanych przez aktywistów umożliwił osiąganie celów propagandowych. Liczba udostępnionych relacji oraz zaangażowanie użytkowników w kreację transnarodowych przestrzeni dyskursywnych mogły spowodować, iż rosyjskie media propagandowe wpłynęły na radykalizację stanowisk protestujących, co pozwoliło na utrzymanie napięć społecznych, jednocześnie uwiarygodniając przekaz propagandowy nadawcy.

\section{Bibliografia}

Bachryj-Krzywaźnia M. (2019). Dedykowany storytelling - psychologiczne przesłanki perswazyjnej efektywności narracyjnego marketingu politycznego. Środkowoeuropejskie Studia Polityczne, nr 1, 193-210.

Bailey O.G., Cammaerts B., Carpentier N. (2012). Media alternatywne. Kraków.

Bryjka F. (2018). Rosyjskie środki aktywne w przestrzeni euroatlantyckiej. W: T. Grabińska, Z. Kuźniar (red.). Bezpieczeństwo personalne a bezpieczeństwo strukturalne, t. 6 (s. 168-180). Warszawa.

Castells M. (2013a). Władza komunikacji, przeł. J. Jedliński, P. Tomanek. Warszawa. 
Castells M. (2013b). Sieci oburzenia i nadziei. Ruchy społeczne w erze internetu, przeł. O. Siara. Warszawa.

Czarnacka A. (2018). Macronowskie tanie państwo okazało się bardzo drogie. O co chodzi protestującym w Paryżu. 2018-11-26, Oko.press [https://oko.press/macronowskie-tanie-panstwo-okazalo-sie-bardzo-drogie-o-co-chodzi-protestujacym-w-paryzu/; 15.05.2019].

Darczewska J. (2014). Anatomia rosyjskiej wojny informacyjnej. Operacja Krymska - Studium przypadku. Warszawa.

Darczewska J. (2016). Rosyjskie siły zbrojne na froncie walki informacyjnej. Dokumenty strategiczne. Warszawa.

Darczewska J., Żochowski P. (2017). Środki aktywne. Rosyjski towar eksportowy. Warszawa [https://www.osw.waw.pl/sites/default/files/pw_64_pl_srodki_aktywne_net.pd; 2.06.2019].

Darczewska J. (2018). Środki aktywne jako rosyjska agresja hybrydowa w retrospekcji. Wybrane problemy. Przegląd Bezpieczeństwa Wewnętrznego, nr 18, s. 40-67.

Endong F.P. (2018). Hashtag Activism and the Transnationalization of Nigerian-born Movements against Terrorism: A Critical Appraisal of the \#bringbackourgirls Campaign. W: F.P. Endong (ed.). Exploring the Role of Social Media in Transnational Advocacy (s. 36-53) [https://www. igi-global.com/viewtitle.aspx?TitleId=202303; 15.05.2019].

Eisenstadt S.N. (2009). Utopia i nowoczesność, przeł. A. Ostolski. Warszawa.

Habermas J. (1989). The Structural Transformation of the Public Sphere: an Inquiry into a Category of Bourgeois Society. Cambridge.

Juris J.S. (2008). Networking Futures, The Movements against Corporate Globalization. Durham. Kershaw I. (1983). How Effective Was Nazi Propaganda? W: D. Welch (ed.). The Power and the Limitations (s. 180-205). London.

Lebelle A. (2018). Gilets jaunes: Le ressentiment est gigantesque, prévient Christophe Guilluy [http://www.leparisien.fr/economie/gilets-jaunes-le-ressentiment-est-gigantesque-previent-christophe-guilluy-17-11-2018-7945053.php; 15.05.2019].

Levinson P. (2010). Nowe nowe media, przeł. M. Zawadzka-Strączek. Kraków.

Lievrouw L.A. (2012). Media alternatywne i zaangażowanie społeczne. Warszawa.

Majorek M. (2015). Kod YouTube. Od kultury partycypacji do kultury kreatywności. Kraków.

Marczewska-Rytko M. (2017). Nowe ruchy społeczne w dobie globalizacji: uwarunkowania i charakterystyka. W: M. Marczewska-Rytko, D. Maj (red.). Nowe ruchy społeczne (s. 15-26). Lublin.

McCombs M.E., Shaw D.L., Weaver D.H. (2014). New Directions in Agenda-setting Theory and Research. Mass Communication and Society, vol. 17, no. 6, p. 781-802.

McQuail D. (2009). Mass Communication Theory. London.

Nowak E. (2016). Teoria agenda-setting a nowe media. Studia Medioznawcze, nr 3, s. 11-24.

Offe C. (2009). Nowe ruchy społeczne: Przekraczanie granic polityki instytucjonalnej. W: P. Sztompka, M. Kucia (red.). Socjologia. Lektury (s. 218-224). Kraków.

Ogrodowczyk P. (2018). „Środki aktywne” - skuteczne działania rosyjskich służb specjalnych. Civitas Hominibus, nr 13, s. 59-73.

Paleczny T. (2010). Nowe ruchy społeczne. Kraków.

Piechota G., Rajczyk R. (2015). The Role of Social Media during Protests on Maidan. Communication Today, no. 2, p. 86-97.

Piechota G. (2018). Pomiędzy happeningiem a zmianą. Znaczenie komunikacji sieciowej w protestach społeczno-politycznych. Kraków. 
Politico. (2019). Fake newsy o „żółtych kamizelkach” miały miliony udostępnień na Facebooku [https://wiadomosci.onet.pl/politico/francja-fake-newsy-o-zoltych-kamizelkach-z-milionem-udostepnien-na-facebooku/7k02546; 15.05.2019].

Polskie Radio 24. (2019). Ekspert: Rosja przez propagandę chce osiągnąć wysoki stan polaryzacji społecznej [https://polskieradio24.pl/130/5925/Artykul/2287436; 5.06.2019].

Rajczyk R. (2016). Współczesne wojny informacyjne. Warszawa.

Sádaba T. (2006). Framing: Una Teoria Para Los Medios de Communicacion. Pamplona.

Stopczyńska K. (2016). Wykorzystanie storytelling w kreowaniu wizerunku marki w social media. Handel Wewnętrzny, nr 3, s. 317-328.

Sunstein C.S. (2018). \#Republic. Divided Democracy in the Age of Social Media. Princeton - Oxford. Sykulski L. (2019). Rosyjska geopolityka a wojna informacyjna. Warszawa.

Volkmer I. (1999). News in the Global Sphere: A Study of CNN and Its Impact on Global Communication. Luton.

Volkmer I. (2014). The Global Public Sphere: Public Communication in the Age of Reflective Interdependence. Cambridge.

Wasilewski J., Olczyk T. (2017). Storytelling jako narzędzie marketingu politycznego - model. Studia Politologiczne, vol. 45, s. 36-53.

Watts C. (2018). Messing with the Enemy. Surviving in a Social Media World of Hackers, Terrorists, Russians and Fake News. New York.

Weiman G., Brosius, H.B. (2016). New Agenda for Agenda-setting Research in the Digital Era. W: G. Vowe, P. Henn (ed.). Political Communication in the Online World: Theoretical Approaches and Research Design (p. 26-44). London.

\section{STRESZCZENIE}

Artykuł dotyczy oddziaływania propagandowego narracji kreowanej podczas protestów politycznych. Zrealizowane badania prezentują aktywność rosyjskich mediów propagandowych podczas rewolucji „żółtych kamizelek” we Francji. W analizie ilościowej potwierdzono przyjętą hipotezę, że tworzenie narracji propagandowej nie musi opierać się na kreowaniu fake newsów i trollingu czy działaniach dezinformacyjnych, jakie zwykle są domeną ingerowania Federacji Rosyjskiej w bezpieczeństwo informacyjne państw trzecich. Skutecznie realizowana propaganda może polegać na intensywnym relacjonowaniu wydarzeń, które budują narrację sprzyjającą wypełnianiu celów propagandowych. Badania potwierdziły istotną rolę mediów społecznościowych używanych jako kanał „opowiadania” o protestach politycznych i wzmacniających zjawiska cyberpolaryzacji. Dzięki tworzeniu sieciowych enklaw deliberacji podtrzymywane jest zainteresowanie protestem, zwiększane są zasięgi udostępnianych informacji oraz aktywizowane antagonizmy pomiędzy grupami społecznymi.

Słowa kluczowe: rewolucja „żółtych kamizelek”, protesty polityczne, Francja, rosyjskie media propagandowe, media społecznościowe 